\title{
Effects of Mindfulness-Based Interventions on Biomarkers and Low-Grade Inflammation in Patients with Psychiatric Disorders: A Meta-Analytic Review
}

\author{
Kenji Sanada ${ }^{1, *(\mathbb{D})}$, Jesus Montero-Marin ${ }^{2}\left(\mathbb{D}\right.$, Alberto Barceló-Soler ${ }^{3,4}$, Daisuke Ikuse ${ }^{1}$, \\ Marie Ota ${ }^{1}$, Akihito Hirata ${ }^{1}$, Akira Yoshizawa ${ }^{1}$, Rieko Hatanaka ${ }^{1}$, Montserrat Salas Valero ${ }^{5}$, \\ Marcelo Demarzo ${ }^{6}{ }^{\circledR}$, Javier García Campayo ${ }^{3,7}$ and Akira Iwanami ${ }^{1}$ \\ 1 Department of Psychiatry, Showa University School of Medicine, Tokyo 157-8577, Japan; \\ ikuself3211731@yahoo.co.jp (D.I.); mariemarie1015@yahoo.co.jp (M.O.); msa473u@gmail.com (A.H.); \\ masao-y@iris.ocn.ne.jp (A.Y.); rhatanaka0@gmail.com (R.H.); iwanami@med.showa-u.ac.jp (A.I.) \\ 2 Department of Psychiatry, University of Oxford, Warneford Hospital, Oxford OX3 7JX, UK; \\ jesus.monteromarin@psych.ox.ac.uk \\ 3 Primary Care Prevention and Health Promotion Research Network, RedIAPP, 28220 Madrid, Spain; \\ abarcelosoler@hotmail.com (A.B.-S.); jgarcamp@gmail.com (J.G.C.) \\ 4 Aragon Institute for Health Research, IIS Aragon, 50009 Zaragoza, Spain \\ 5 Aragon Health Sciences Institute, IACS, 50009 Zaragoza, Spain; msalas.iacs@aragon.es \\ 6 Mente Aberta-Brazilian Center for Mindfulness and Health Promotion, Department of Preventive Medicine, \\ Universidade Federal de São Paulo, São Paulo 13565-905, Brazil; demarzo@unifesp.br \\ 7 Instituto de Investigación Sanitaria Aragón, Hospital Universitario Miguel Servet, 50009 Zaragoza, Spain \\ * Correspondence: ksanappu@gmail.com
}

Received: 16 March 2020; Accepted: 30 March 2020; Published: 3 April 2020

check for updates

\begin{abstract}
Mindfulness-Based Interventions (MBIs) present positive effects on mental health in diverse populations. However, the detailed associations between MBIs and biomarkers in patients with psychiatric disorders remain poorly understood. The aim of this study was to examine the effects of MBIs on biomarkers in psychiatric illness used to summarise the effects of low-grade inflammation. A systematic review of PubMed, EMBASE, PsycINFO, and the Cochrane Library was conducted. Effect sizes (ESs) were determined by Hedges' $\mathrm{g}$ and the number needed to treat (NNT). Heterogeneity was evaluated. A total of 10 trials with 998 participants were included. MBIs showed significant improvements in the event-related potential amplitudes in attention-deficit hyperactivity disorder, the methylation of serotonin transporter genes in post-traumatic stress disorder, the salivary levels of interleukin 6 (IL-6) and tumour necrosis factor alpha (TNF- $\alpha$ ) in depression, and the blood levels of adrenocorticotropic hormone (ACTH), IL-6, and TNF- $\alpha$ in generalised anxiety disorder. MBIs showed low but significant effects on health status related to biomarkers of low-grade inflammation $(g=-0.21 ; 95 \%$ confidence interval $(\mathrm{CI})-0.41$ to -0.01 ; NNT $=8.47$ ), with no heterogeneity $\left(I^{2}=0 ; 95 \%\right.$ CI 0 to 79$)$. More trials are needed to establish the impact of MBIs on biomarkers in psychiatric illness.
\end{abstract}

Keywords: mindfulness-based interventions; biomarkers; low-grade inflammation; psychiatric disorders; meta-analysis

\section{Introduction}

Mindfulness is a theoretical construct that comes from Eastern spiritual traditions, especially Buddhism, and that has been recently adapted to Western culture and science. The word "mindfulness" is the English translation of sati (Pali) or smriti (Sanskrit) which implies "bare attention" or 
"present-centred awareness" [1]. Kabat-Zinn introduced this therapeutic approach in the field of health in the 1970s [2], and defining mindfulness as the state of mind that arises from paying attention in a particular way, on purpose, in the present moment and without judgement [3]. He developed Mindfulness-Based Stress Reduction (MBSR) as a group treatment, reporting its effectiveness in patients with chronic pain [4]. Since then, new standardised intervention approaches based on MBSR have been developed, such as Mindfulness-Based Cognitive Therapy (MBCT), which aims to prevent relapses in depression [5], and Mindfulness-Based Relapse Prevention, which reduces the probability and severity of relapse in patients with substance use disorders [6,7]. These programmes are described as Mindfulness-Based Interventions (MBIs), with specific psychoeducational components adapted to the target population $[1,8]$.

Although psychometric assessments of MBIs are generally limited, recent meta-analyses have shown the significant efficacy of MBIs for clinical symptoms of psychiatric disorders [9,10]; the authors reported that MBIs were equivalent to evidence-based treatments at post-treatment as well as at follow-up. Likewise, their positive effects on psychiatric symptoms have been found in patients with depression [11-13], anxiety [14-16], addictive disorders [17-19], insomnia [20,21], and somatoform disorder [22]. These previous studies indicate that mindfulness acts on different physiological markers related to anxiety by reducing cortisol, C-reactive protein (CRP), blood pressure, heart rate, triglycerides and tumour necrosis factor alpha (TNF- $\alpha)$.

With regard to the scope of the study of mindfulness and its effects on neuroinflammation, the biomarkers that have been examined are the pro-inflammatory cytokines interleukin 6 (IL-6) [23-26], IL-8 [23,27], TNF- $\alpha$ [24-26] and interferon gamma (IFN- $\gamma$ ) [28-30]; the anti-inflammatory cytokines IL-4 [28] and IL-10 [24]; neuropeptides, such as neuropeptide Y [31]; and CRP [27,32]. In addition, although low-grade inflammation is generally determined by increased levels of high-sensitive CRP (hsCRP) [33,34], it is also reflected by increased concentrations of pro-inflammatory cytokines and acute phase proteins, such as CRP [35].

Despite the current evidence on mindfulness and biomarkers, the relationship between mindfulness and biomarkers in patients with psychiatric disorders remain poorly understood. Thus, the aim of this systematic review was to examine the effects of MBIs on biomarkers in patients with psychiatric disorders and to meta-analyse effects on low-grade inflammation from studies available to date.

\section{Methods}

This systematic review followed the Preferred Reporting Items for Systematic Reviews and Meta-Analyses (PRISMA) guidelines [36] and the recommendations of the Cochrane Collaboration [37]. The protocol was registered with the International Prospective Register of Systematic Reviews (PROSPERO) (registration number CRD42018084768).

\subsection{Eligibility Criteria}

The study's eligibility criteria are shown in Table 1 . We excluded studies for the following reasons: (1) inappropriate article type (i.e., study protocol) $[38,39]$ and (2) inappropriate diagnostic procedure [40]. The articles that provided enough data to calculate effect size estimations of low-grade inflammatory biomarkers when comparing an MBI group with a control group were selected for the quantitative synthesis. 
Table 1. Study eligibility criteria.

\begin{tabular}{lll}
\hline & Inclusion Criteria & Exclusion Criteria \\
\hline Participants & $\begin{array}{l}\text { Patients with psychiatric disorders according to either } \\
\text { a formal diagnosis interview and/or a cut-off for clinical }\end{array}$ & Patients with other disorders, and only healthy subjects. \\
& symptoms in a rating scale; No restrictions were placed & \\
on age. & Mindfulness-based interventions (MBIs) & Other non-pharmacological interventions. \\
Interventions & At least one biomarker. & No biomarkers. \\
$\begin{array}{l}\text { Outcome } \\
\text { Study design }\end{array}$ & RCTs, Non-RCTs, Open trials with a pre-post analysis. & $\begin{array}{l}\text { Study protocols, cross-sectional studies, qualitative } \\
\text { studies }\end{array}$ \\
Publications & Published as full-text articles in peer-reviewed scientific $\begin{array}{l}\text { Published as reviews, case reports, conference abstracts, } \\
\text { or letters. }\end{array}$ & \\
\hline
\end{tabular}

Abbreviations: Non-RCTs, non-randomised controlled trials; RCTs, randomised controlled trials. 


\subsection{Search Strategy}

A systematic computerised literature search of PubMed, EMBASE, PsycINFO and Cochrane Library was conducted by an expert in this field (M.S. Valero); in order to avoid language publication bias, there were no restrictions on language. As an example, the searching strategy for the PubMed database can be seen in Table 2. The reference lists of the identified original articles and reviews were also searched manually for additional studies that may have been missed. The last search was conducted on 26 November 2019.

Table 2. Searching strategy for the PubMed database.

("psychiatric disorders"[All Fields] OR "psychiatric disturbances"[All Fields] OR "psychiatric"[All Fields])
AND ("mindfulness"[MeSH Terms] OR "mindfulness"[All Fields] OR mbct[tiab] OR mbsr[tiab] OR
"Mindfulness-Based Cognitive Therapy"[tiab] OR "Mindfulness Based Stress Reduction"[tiab] OR
"MBI"[tiab] OR "mindfulness-based interventions"[tiab] OR meditation[tiab]) AND
("biomarkers"[MeSH Terms] OR "biomarkers"[All Fields] OR "biomarker"[All Fields] OR "biological
markers"[All Fields] OR "biological marker"[All Fields]).

\subsection{Study Selection}

Three authors (D. Ikuse, M. Ota and A. Yoshizawa) independently screened all titles and abstracts to identify possible articles for full text retrieval. The full texts of potentially eligible articles were assessed independently by the same three reviewers. Any discrepancies or divergences were resolved by discussion and consensus, and when in doubt, the final decision was made in consultation with a fourth author (K. Sanada).

\subsection{Data Extraction}

Using a predefined data extraction sheet, we extracted data for the following items: year of publication, characteristics of the groups and participants (i.e., number of participants, diagnoses of participants, age, gender), definition of psychiatric disorders, characteristics of MBIs and controls (type of intervention, length of intervention in total weeks), biomarkers (source, type) and study design.

\subsection{Assessment of Study Quality}

In the present systematic review, risk of bias was assessed with the Cochrane Collaboration tool [41] to assess possible sources of bias: sequence generation, allocation concealment, blinding of participants and personnel, blinding of outcome assessment, incomplete outcome data, selective outcome reporting and other sources of bias. The risk of bias tool is generally used for randomised controlled trials (RCTs), but it can also be applied to non-RCTs. Three reviewers (D. Ikuse, M. Ota and A. Yoshizawa) independently assessed these biases, and any disagreements between the authors were resolved through discussion or consultation with a fourth reviewer (K. Sanada). The quality of interventions was assessed by means of three criteria [42]: 1) use of a treatment manual, 2) provision of therapy by specifically trained therapists, and 3) verification of treatment integrity during the study.

\subsection{Data Synthesis}

Measurements were collected from the outcomes of such indices as adrenocorticotropic hormone (ACTH), cortisol (area under the curve or AUC, awakening response or CAR, and diurnal slope), cytokines (IL-6, IL-8 and TNF- $\alpha$ ), nuclear factor enhancer of the kappa light chains of activated B cells (NF-kB), high-sensitive CRP (hsCRP) and epidermal growth factor (EGF). ACTH is a melanocortin peptide produced in response to inflammatory mediators, with higher levels indicating a worse health status [43]. AUC is one of the methods for analysing the overall secretion of cortisol over a specific time-period (e.g., a whole day) in endocrinologic studies, with a higher AUC output considered to be an indicator of worse health status $[8,44,45]$. CAR is defined as the change in cortisol concentration that occurs during the first hour after waking from sleep [46] and low CAR values have been associated 
with low health states such as fatigue and burnout $[8,47]$. The diurnal slope is a method for analysing cortisol concentrations focused on the diurnal cycle, in which levels of cortisol are high in the morning and low at night, so that higher morning levels and diurnal slope values are considered to indicate a better health status $[8,48,49]$. The IL-6, IL- 8 and TNF- $\alpha$ cytokines are of a pro-inflammatory type, and thus the higher the levels, the worse the state of health [50-52]. NF-kB is a pro-inflammatory transcription factor in which higher values correspond to worse health status [53]. High-sensitive CRP (hsCRP) is more sensitive than standard CRP, and there are some relationships between hsCRP and cardiovascular disease [54], with higher levels indicating a worse health status. EGF has been related to stress and mood disorders [55,56], with decreased levels being associated with improvements in symptoms.

We examined the post-treatment measurements of low-grade inflammation that were collected immediately after the intervention. The effect size (ES), indicating the differences between the two groups (MBI vs control), and 95\% confidence intervals (CIs) were calculated. Hedges' $\mathrm{g}$ was chosen as the ES measure, since the present analysis included studies with a small sample size, and this measure adjusts accordingly [57]. If necessary, combined outcomes were estimated using a pooled mean ES. We also converted Hedges' $g$ into the number needed to treat (NNT), according to Furukawa's formula [58]. NNT indicates the number of participants who need to be treated in order to generate one additional, clinically significant, favourable change [59]. We tested heterogeneity using the $I^{2}$ statistic and $95 \% \mathrm{CI}$, assuming a value of around $25 \%$ to indicate low heterogeneity, $50 \%$ to indicate moderate and $75 \%$ to indicate high heterogeneity [60]. We also calculated the $Q$ statistic and the associated $p$-value. Publication bias was assessed initially through the construction of a funnel plot analysis [61]. Egger's test was used to contrast the null hypothesis with biased absences [62], and Duval and Tweedie's trim and fill procedure [63] provided the number of studies that were probably absent. The Begg and Mazumdar rank correlation test was also applied to test whether the adjusted and observed ESs differed significantly from each other [64]. All of the tests were two-sided and were performed with a significance level of $p<0.05$, except for the bias-related tests, which were one-sided.

\section{Results}

\subsection{Search Results}

We identified 213 titles and abstracts from PubMed (12), EMBASE (167), PsycINFO (9), and the Cochrane Library (25). We also identified seven possible additional records through other sources. There were 183 records after duplicate removal, 168 of which were excluded because they did not meet the inclusion criteria (Figure 1). A total of 15 articles were retrieved for eligibility and possible inclusion in the database. Of these, we finally selected 10 studies that examined the efficacy of MBIs on biomarkers in patients with psychiatric disorders. The PRISMA flow chart is shown in Figure 1. In the included studies, seven used RCTs [23,26,65-69], the remaining three being open-label studies [70-72]. The majority of studies did not include a follow-up assessment time point $(70 \%)$. Six studies focused on depression and/or anxiety disorder, or depressive symptoms $[23,26,65,68,69,71]$, one on alcohol dependence [70], one on attention-deficit hyperactivity disorder (ADHD) [66], one on sleep disturbance [67] and the other on post-traumatic stress disorder (PTSD) [72]. Six studies were conducted in the United States $(60 \%)$ and the others in Europe. The characteristics of the 10 studies included for qualitative synthesis are listed in Table 3. 

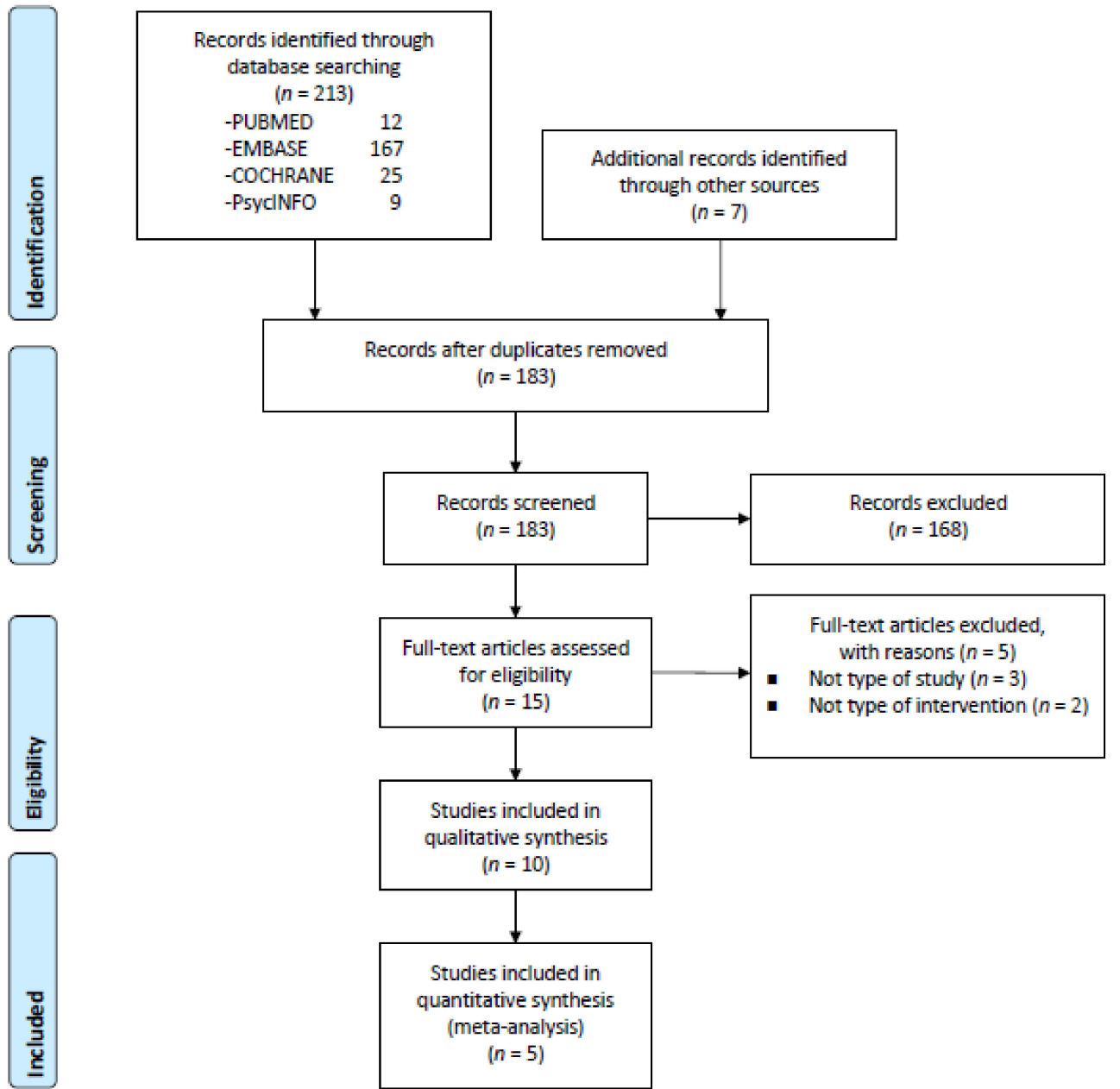

Figure 1. PRISMA flow chart of study selection. 
Table 3. Characteristics of studies included in the systematic review.

\begin{tabular}{|c|c|c|c|c|c|c|c|c|c|c|c|}
\hline Study & Population & $\begin{array}{l}\text { Age Mean (SD) } \\
\text { or IQR }\end{array}$ & $\begin{array}{l}\text { Sex } \\
(\% \mathrm{~F})\end{array}$ & Outcomes & $\begin{array}{l}\text { MBI } \\
\text { Program }\end{array}$ & Controls & $\begin{array}{l}\text { Follow } \\
\text { Up (M) }\end{array}$ & Results & $\begin{array}{l}\text { Definition of } \\
\text { Psychiatric } \\
\text { Disorders }\end{array}$ & Sd & In \\
\hline \multirow{3}{*}{$\begin{array}{l}\text { Zgierska } \\
2008[70] \\
\text { US }\end{array}$} & \multirow{3}{*}{$\begin{array}{l}\text { Alcohol } \\
\text { dependence }\end{array}$} & \multirow[t]{3}{*}{$38.4(8.6)$} & \multirow[t]{3}{*}{52.6} & \multirow{3}{*}{$\begin{array}{l}\text { IL-6, } \\
\text { cortisol } \\
\text { serum, } \\
\text { salivary }\end{array}$} & MM & \multirow[t]{3}{*}{ None } & \multirow[t]{3}{*}{4} & $\begin{array}{l}\text { IL-6 levels decreased from baseline to 16-week } \\
\text { follow-up }\end{array}$ & \multirow[t]{3}{*}{ DSM-IV } & \multirow[t]{3}{*}{ Open } & + \\
\hline & & & & & $(n=19)$ & & & $(p=0.052)$ & & & + \\
\hline & & & & & 8 weeks & & & $\begin{array}{l}\text { There were no significant changes in salivary } \\
\text { cortisol levels } \\
\text { from baseline to } 16 \text {-week follow-up. }\end{array}$ & & & + \\
\hline \multirow{3}{*}{$\begin{array}{l}\text { Gex-Fabry } \\
\text { 2012 [65] } \\
\text { Switzerland } \\
\end{array}$} & \multirow{3}{*}{$\begin{array}{l}\text { Remitted } \\
\text { from } \\
\text { recurrent } \\
\text { MDD }\end{array}$} & \multirow[t]{3}{*}{$24-66$} & \multirow[t]{3}{*}{71.4} & \multirow{3}{*}{$\begin{array}{l}\text { cortisol } \\
\text { salivary }\end{array}$} & $\begin{array}{l}\mathrm{MBCT}+ \\
\text { TAU }\end{array}$ & TAU & \multirow[t]{3}{*}{12} & \multirow{3}{*}{$\begin{array}{l}\text { No significant changes in cortisol indices from } \\
\text { baseline to the } \\
\text { end of intervention were observed between } \\
\text { both groups. }\end{array}$} & \multirow{3}{*}{$\begin{array}{l}\text { DSM-IV } \\
\text { MADRS } \leq 13\end{array}$} & \multirow[t]{3}{*}{ RCT } & + \\
\hline & & & & & $(n=28)$ & $(n=28)$ & & & & & + \\
\hline & & & & & 8 weeks & 8 weeks & & & & & + \\
\hline \multirow{3}{*}{$\begin{array}{l}\text { Schoenberg } \\
\text { 2014 [66] } \\
\text { Netherlands } \\
\end{array}$} & \multirow[t]{3}{*}{ ADHD } & \multirow[t]{3}{*}{$19-53$} & \multirow[t]{3}{*}{52.3} & \multirow[t]{3}{*}{ ERP } & МBCT & $\mathrm{WL}$ & \multirow[t]{3}{*}{ No } & \multirow{3}{*}{$\begin{array}{l}\text { In the MBCT group, there was a significant } \\
\text { increase in Pe and } \\
\text { NoGo-Pa amplitudes ( } p=0.02 \text { and } \\
p=0.02 \text {, respectively). }\end{array}$} & \multirow[t]{3}{*}{ DSM-IV } & \multirow[t]{3}{*}{ RCT } & ? \\
\hline & & & & & $(n=24)$ & $(n=20)$ & & & & & + \\
\hline & & & & & 12 weeks & & & & & & \\
\hline Black & \multirow{3}{*}{$\begin{array}{l}\text { Sleep } \\
\text { disturbance }\end{array}$} & \multirow[t]{3}{*}{$66.3(7.4)$} & \multirow[t]{3}{*}{67.3} & \multirow{3}{*}{$\begin{array}{l}\text { NF-kB } \\
\text { plasma }\end{array}$} & MAPs & Education & \multirow[t]{3}{*}{ No } & \multirow{3}{*}{$\begin{array}{l}\text { There was a significant reduction overtime in the } \\
\text { levels of NF- } \\
\mathrm{kB} \text { in both groups }(p=0.26) \text {. } \\
\text { No significant difference in NF-kB concentrations } \\
\text { was observed } \\
\text { between the groups. }\end{array}$} & \multirow[t]{3}{*}{$\mathrm{PSQI} \geq 5$} & \multirow[t]{3}{*}{ RCT } & - \\
\hline 2015 [67] & & & & & $(n=24)$ & $(n=25)$ & & & & & + \\
\hline us & & & & & 6 weeks & 6 weeks & & & & & - \\
\hline \multirow{2}{*}{$\begin{array}{l}\text { Eisendrath } \\
\text { 2016 [71] } \\
\text { US }\end{array}$} & MDD & $34.9(7.9)$ & 72.7 & CRP & МВСТ & None & No & $\begin{array}{l}\text { There was not significantly decrease in CRP levels } \\
\text { from pre- to }\end{array}$ & SCID DSM-IV & Open & $?$ \\
\hline & & & & serum & $\begin{array}{l}(n=11) \\
8 \text { weeks }\end{array}$ & & & post-intervention $(p=0.0517)$ & $\mathrm{HAMD}_{17}$ & & + \\
\hline
\end{tabular}


Table 3. Cont

\begin{tabular}{|c|c|c|c|c|c|c|c|c|c|c|c|}
\hline Study & Population & $\begin{array}{l}\text { Age Mean (SD) or } \\
\text { IQR }\end{array}$ & $\begin{array}{l}\text { Sex } \\
(\% \mathrm{~F})\end{array}$ & Outcomes & $\begin{array}{l}\text { MBI } \\
\text { Program }\end{array}$ & Controls & $\begin{array}{l}\text { Follow } \\
\text { Up (M) }\end{array}$ & Results & $\begin{array}{l}\text { Definition of } \\
\text { Psychiatric } \\
\text { Disorders }\end{array}$ & $\mathrm{Sd}$ & In \\
\hline $\begin{array}{l}\text { Walsh } \\
\text { 2016 [68] } \\
\text { US }\end{array}$ & $\begin{array}{l}\text { Depressive } \\
\text { symptoms }\end{array}$ & $19.1(0.1)$ & 100 & $\begin{array}{l}\text { IL-6, } \\
\text { TNF- } \alpha \\
\text { salivary }\end{array}$ & $\begin{array}{l}\text { Mindfulness } \\
(n=31) \\
4 \text { weeks }\end{array}$ & $\begin{array}{l}\text { Contact } \\
\text { Control } \\
(n=33) 4 \\
\text { weeks }\end{array}$ & 3 & $\begin{array}{l}\text { Mindfulness training predicted significant } \\
\text { decreases in the } \\
\text { levels of IL-6 and TNF- } \alpha(p<0.001 \text { and } p=0.013 \text {, } \\
\text { respectively). }\end{array}$ & CES-D $\geq 16$ & RCT & $\begin{array}{l}+ \\
+ \\
-\end{array}$ \\
\hline $\begin{array}{l}\text { Memon } \\
\text { 2017 [23] } \\
\text { Sweden }\end{array}$ & $\begin{array}{l}\text { MDD, AD } \\
\text { or SD } \\
\text { and } \\
\text { adjustment } \\
\text { disorders }\end{array}$ & $41.5(11.0)$ & 87.3 & $\begin{array}{l}\text { IL-6, IL-8, } \\
\text { EGF, } \\
\text { hsCRP } \\
\text { plasma }\end{array}$ & $\begin{array}{l}\text { Mindfulness } \\
(n=81) \\
8 \text { weeks }\end{array}$ & $\begin{array}{l}\text { TAU (CBT) } \\
(n=85) \\
8 \text { weeks }\end{array}$ & No & $\begin{array}{l}\text { EGF levels were significantly decreased from } \\
\text { baseline to post- } \\
\text { intervention in both groups ( } p<0.001 \text {, both). } \\
\text { No significant changes in the levels of IL-8 and } \\
\text { hscCR from } \\
\text { baseline to post-intervention were found in both } \\
\text { groups. }\end{array}$ & $\begin{array}{l}\text { ICD-10 } \\
\text { PHQ- } 9 \geq 10 \text { or } \\
\text { HADS-D } \geq 7 \\
\text { or HADS-A } \geq 7 \\
\text { or } 13 \leq \text { MADRS } \\
\leq 34\end{array}$ & RCT & $\begin{array}{l}- \\
+ \\
-\end{array}$ \\
\hline $\begin{array}{l}\text { Wang } \\
\text { 2017 [69] } \\
\text { Sweden }\end{array}$ & $\begin{array}{l}\text { MDD, AD } \\
\text { or SD } \\
\text { and } \\
\text { adjustment } \\
\text { disorders }\end{array}$ & $\begin{array}{l}\text { Pt: } \\
41.9(11.1) \\
\text { Ct: } \\
44.6(12.5)\end{array}$ & $\begin{array}{l}\text { Pt: } \\
87.8 \\
\text { Ct: } \\
38.4\end{array}$ & LTL & $\begin{array}{l}\text { Mindfulness } \\
(n=88) \\
\text { 8weeks }\end{array}$ & $\begin{array}{l}\text { TAU (CBT) } \\
(n=89) \\
8 \text { weeks } \\
\text { HCs } \\
(n=320)\end{array}$ & No & $\begin{array}{l}\text { At baseline, telomere length was significantly } \\
\text { shorter in the } \\
\text { patients compared to the controls }(p=0.006) \text {. } \\
\text { There were no significant changes in the telomere } \\
\text { length from } \\
\text { baseline to post-intervention in both the } \\
\text { Mindfulness and the } \\
\text { TaU groups, and was no significant difference } \\
\text { between the } \\
\text { groups. }\end{array}$ & $\begin{array}{l}\text { ICD-10 } \\
\text { PHQ-9 } \geq 10 \text { or } \\
\text { HADS-D } \geq 7 \\
\text { or HADS-A } \geq 7 \\
\text { or } 13 \leq \text { MADRS } \\
\leq 34\end{array}$ & RCT & $\begin{array}{l}- \\
+ \\
+\end{array}$ \\
\hline
\end{tabular}


Table 3. Cont.

\begin{tabular}{|c|c|c|c|c|c|c|c|c|c|c|c|}
\hline Study & Population & $\begin{array}{l}\text { Age Mean (SD) or } \\
\text { IQR }\end{array}$ & $\begin{array}{l}\text { Sex } \\
(\% \mathrm{~F})\end{array}$ & Outcomes & $\begin{array}{l}\text { MBI } \\
\text { Program }\end{array}$ & Controls & $\begin{array}{l}\text { Follow } \\
\text { Up (M) }\end{array}$ & Results & $\begin{array}{l}\text { Definition of } \\
\text { Psychiatric } \\
\text { Disorders }\end{array}$ & Sd & In \\
\hline Bishop & PTSD & Res: & Res: & SLC6A4 & MBSR & None & No & $\begin{array}{l}\text { There was a significant time } \times \text { responder group } \\
\text { interaction for }\end{array}$ & DSM-IV & Open & + \\
\hline 2018 [72] & & $60.4(14.5)$ & 18.0 & FKBP5 & $\begin{array}{l}\text { (Res: } n= \\
11)\end{array}$ & & & methylation in $F K B P 5$ intron 7 bin $2(p=0.013)$. & PCL, CAPS & & + \\
\hline \multirow[t]{2}{*}{ us } & & Non-Res: & Non-Res: & & $\begin{array}{l}\text { (Non-Res: } \\
n=11)\end{array}$ & & & $\begin{array}{l}\text { A significant correlation between } F K B P 5 \text { intron } 7 \\
\text { bin } 2\end{array}$ & & & + \\
\hline & & $58.2(10.2)$ & 18.0 & & 9 weeks & & & $\begin{array}{l}\text { methylation change and PCL change from before } \\
\text { to after } \\
\text { treatment was observed }(r=-0.451, p=0.04) \text {. } \\
\text { There was no effect of time for methylation } \\
\text { changing in the } \\
\text { Primary component of SLC6A4. }\end{array}$ & & & \\
\hline Hoge & GAD & $39.2(12.8)$ & 45.7 & $\begin{array}{l}\text { cortisol, } \\
\text { ACTH, LL-6 }\end{array}$ & MBSR & Education & No & $\begin{array}{l}\text { MBSR group showed a greater reduction in ACTH, } \\
\text { TNF- } \alpha \text { and }\end{array}$ & SCID DSM-IV & RCT & + \\
\hline 2018 [26] & & & & $\begin{array}{l}\text { TdF- } \alpha \\
\text { during } \\
\text { TSST }\end{array}$ & $(n=42)$ & $(n=28)$ & & $\begin{array}{l}\text { IL-6 Area Under the Curve (AUC) concentrations } \\
\text { compared to }\end{array}$ & & & + \\
\hline us & & & & plasma & 8 weeks & 8 weeks & & $\begin{array}{l}\text { control group ( } p=0.007, p=0.033, p=0.036 \text {, } \\
\text { respectively). }\end{array}$ & & & + \\
\hline
\end{tabular}

Abbreviations: SD, standard deviation; IQR, interquartile range; F, female; MBI, mindfulness-based intervention; M, month; Sd, study design; In, intervention quality (Chambless, 1998): low (-) / high ( + ) / unclear (?), from top to down: the study referred to the use of a treatment manual; the therapists who conducted the therapy were trained; treatment integrity was checked during the study; US, United States; IL, interleukin; MM, mindfulness meditation; DSM-IV, Diagnostic and Statistical Manual of Mental Disorders-Fourth Edition; MDD, major depressive disorder; MBCT, mindfulness-based cognitive therapy; TAU, treatment as usual; MADRS, Montgomery Åsberg Depression Rating Scale; RCT, randomised controlled trial; ADHD, attention-deficit hyperactivity disorder; ERP, event-related potential; WL, wait-list; Pe, error-positivity; NF, nuclear factor; MAPs, mindful awareness practices; PSQI, Pittsburgh Sleep Quality Index; CRP, C-reactive protein; SCID, structured clinical interview for DSM-IV; HAMD 17 , Hamilton Depression Rating Scale-17; TNF- $\alpha$, tumour necrosis factor- $\alpha$; CES-D, Center for Epidemiologic Studies-Depression Scale; AD, anxiety disorder; SD, stress disorder; EGF, epidermal growth factor; hsCRP, high sensitivity C-reactive protein; CBT, cognitive behavioural therapy; ICD-10, International Statistical Classification of Diseases and Related Health Problems-10; PHQ-9, Patient Health Questionnaire-9; HADS-D, Hospital Anxiety and Depression Scale-Depression; HADS-A, Hospital Anxiety and Depression Scale-Anxiety; Pt, patients; Ct, controls; LTL, Leukocyte telomere length; HCs, healthy controls; PTSD, Post-traumatic stress disorder; Res, responders; PCL, PTSD Checklist; CAPS, Clinician-Administered PTSD Scale; GAD, generalised anxiety disorder; ACTH, adrenocorticotropic hormone; TSST, Trier Social Stress Test; MBSR, mindfulness-based stress reduction. 


\subsection{Participants}

The total number of participants across the included studies was 998 (641 women, 64\%). These comprised 19 patients with alcohol dependence [70], 56 remitted patients with recurrent depression [65], 44 patients with ADHD [66], 49 patients with moderate sleep disturbance [67], 11 patients with major depressive disorder (MDD) [71], 64 participants with depressive symptoms [68], 166 patients with mild to moderate depression or anxiety [23], 177 patients with depression, anxiety or stress and adjustment disorders (and 320 healthy controls) [69], 22 patients with PTSD [72] and 70 patients with generalised anxiety disorder (GAD) [26]. Of the data available $(n=898)$, the mean age of the participants was $42.6(\mathrm{SD}=14.3)$ years. As stated in the inclusion criteria, all included studies in this review used a dichotomous measure for psychiatric disorders, namely, a diagnostic interview (Diagnostic and Statistical Manual of Mental Disorders-Fourth Edition [DSM-IV], Structured Clinical Interview for DSM-IV [SCID], International Statistical Classification of Diseases and Related Health Problems-10 [ICD-10]) and/or a cut-off for clinical symptoms on a rating scale (Montgomery-Åsberg Depression Rating Scale [MADRS], Pittsburgh Sleep Quality Index [PSQI], Hamilton Depression Rating Scale [HAMD], Center for Epidemiologic Studies-Depression Scale [CES-D], Patient Health Questionnaire-9 [PHQ-9], Hospital Anxiety and Depression Scale-Depression [HADS-D], Hospital Anxiety and Depression Scale-Anxiety [HADS-A]).

\subsection{Quality of Studies and Interventions}

The risk of bias in the included studies is shown in Figures 2 and 3. Of the 10 studies included for qualitative synthesis, only two $[67,69]$ showed a "low risk" of bias for at least five items. Out of seven items, only one item, "selective outcome reporting", was considered to have a "low risk of bias". With regard to the quality of the interventions, the use of a treatment manual was reported in five trials, therapist training in all trials and treatment integrity in four trials. The corresponding detailed assessment is shown in Table 3.

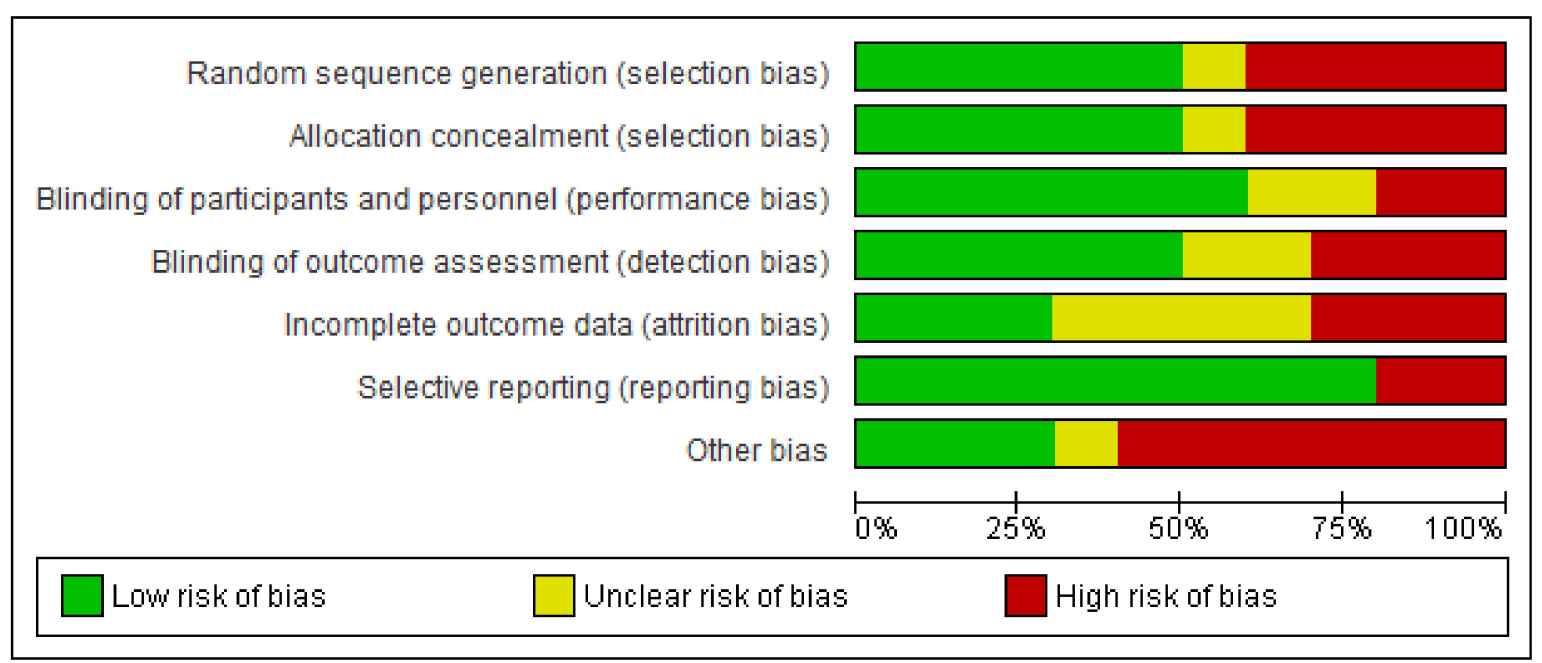

Figure 2. Risk-of-bias graph: reviews the authors' judgments about each risk-of bias item presented as percentages across all of the included studies. 


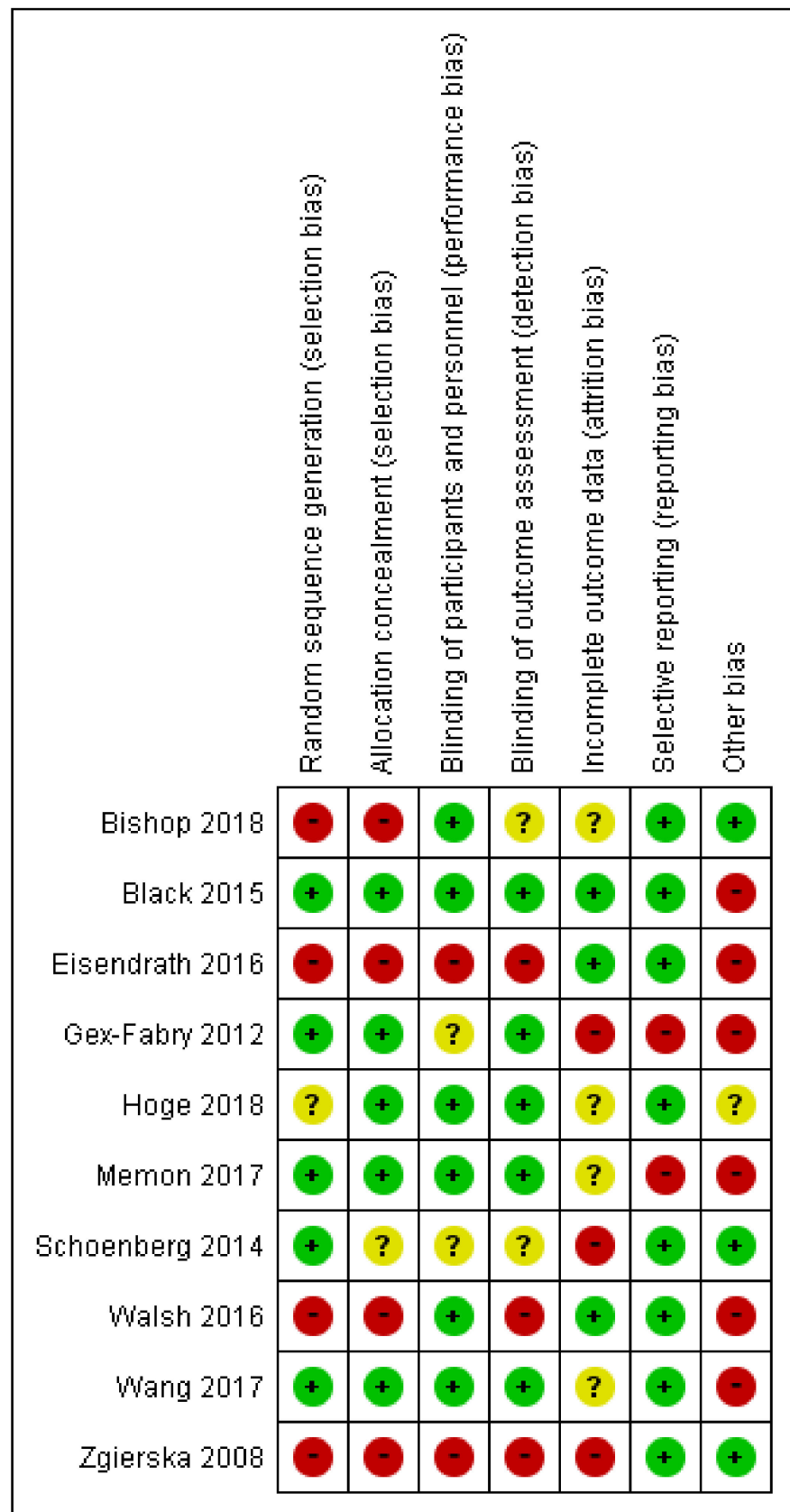

Low risk of bias, ? Unclear, - High risk of bias

Figure 3. Risk-of-bias summary: review of the authors' judgments about each risk-of-bias item for each included study.

\subsection{Biomarkers}

Of the articles reviewed, the biomarkers mainly came from blood samples while four studies used salivary $[65,68,70]$ and electroencephalogram (EEG) [66] samples. The biomarkers included blood IL-6 in patients with depression or anxiety [23], GAD [26], and alcohol dependence [70], salivary IL-6 in subjects with depressive symptoms [68], salivary cortisol in remitted patients with recurrent depression [65] and in patients with alcohol dependence [70], blood cortisol in patients with GAD [26], CRP in patients with MDD [71], hsCRP in patients with depression or anxiety [23], blood TNF- $\alpha$ in patients with GAD [26], salivary TNF- $\alpha$ in subjects with depressive symptoms [68], ACTH in patients with GAD [26], EGF in patients with depression or anxiety [23], IL-8 in patients with depression or anxiety [23], leukocyte telomere length in patients with depression or anxiety [69], NF-kB in patients 
with sleep disturbance [67] and event-related potential (ERP) in patients with ADHD [66]. Of the included studies, IL-6 and cortisol were the most frequently examined (three studies), followed by CRP and TNF- $\alpha$ (two studies); one study [23] did not ultimately analyse the levels of plasma IL-6 due to test sensitivity issues.

\subsection{Mindfulness-Based Interventions (MBIs)}

For the most part, MBIs comprised two types: MBSR [26,72] and MBCT [65,66,71]. Four studies were conducted with modified versions of MBSR, namely, mindfulness meditation relapse prevention [70], mindful awareness practices (MAPs) [67] and mindfulness-based group therapy [23,69]; another was performed with a brief MBI [68]. In six studies, the intervention lasted eight weeks [23,26,65,69-71]. The interventions in the other four studies lasted 12 weeks [66], nine weeks [72], six weeks [67] and four weeks [68].

\subsection{Effectiveness of MBIs on Biomarkers}

There was a high heterogeneity of biomarkers and participants, with studies showing a low quality in general. As observed in Table 3, MBIs showed some effects on biomarkers in six studies $[26,66,68,70-72]$.

Statistically significant findings were found in four trials [26,66,68,72]. One trial [66] examined the effectiveness of a 12-week MBCT intervention on ERP in 50 patients with ADHD. Of the participants, 26 patients were randomised to an MBCT group, and 24 to a wait-list group. ERP, including error-positivity (Pe), conflict monitoring (NoGo-N2) and inhibitory control (NoGo-P3), was evaluated by recording EEG concomitant with a standard visual continuous performance task (CPT-X). The authors reported that MBCT enhanced Pe and NoGo-P3 ERP amplitudes $(p=0.02$ and $p=0.02$, respectively); increased Pe amplitudes were correlated with a reduction in hyperactivity/impulsivity symptoms, and enhanced NoGo-P3 amplitudes were associated with an improvement in inattention symptoms. Another trial [68] investigated the effects of a four-week MBI on salivary IL- 6 and TNF- $\alpha$ in 64 participants with depressive symptoms; 31 participants were randomly allocated to the mindfulness group and 33 participants to the contact control group. MBI predicted significantly lower levels of IL- 6 and TNF- $\alpha$ at post-treatment $(p<0.001$ and $p=0.013$, respectively). Another trial [72] reported DNA methylation related with treatment response to a nine-week MBSR intervention in 22 veterans with PTSD. The authors categorised the participants as responders $(n=11)$ and non-responders $(n=11)$ on the basis of a 10 point or more reduction on a PTSD Checklist (PCL) for symptom severity. There were significant methylation changes related to treatment response in FKBP5 intron 7 bin 2 after a nine-week MBSR $(p=0.013)$. The other trial [26] investigated the effects of an eight-week MBSR intervention on stress response to the laboratory-based Trier Social Stress Test (TSST) in 70 patients with GAD. Of these subjects, 42 were randomly allocated to an MBSR group and 28 to the attention control group. The peripheral biomarkers, namely cortisol, ACTH, IL- 6 and TNF- $\alpha$, were measured at three TSST time periods: pre-stress, immediate post-stress and later post-stress. Statistically significant changes in the AUC concentrations for ACTH, TNF- $\alpha$ and IL- 6 from baseline to post intervention were found in the MBSR group compared to the control group $(p=0.007, p=0.033$, $p=0.036$, respectively).

Two open-label trials [70,71] reported benefits from MBIs in improving inflammatory biomarkers. Zgierska et al. [70] conducted an eight-week mindfulness meditation for 19 patients with alcohol dependence, with 16-week follow-up assessments of serum IL-6 and salivary cortisol. Although no significant changes in the levels of salivary cortisol from baseline to 16 weeks were found, serum IL-6 levels decreased, showing a trend at 16 weeks compared with baseline $(p=0.052)$, with a moderately high ES (Cohen's $d=0.6$ ). Eisendrath et al. [71] conducted an eight-week MBCT for 11 patients with MDD and assessed the levels of serum CRP at pre- and post-intervention. Serum CRP levels from preto post-intervention decreased, showing a trend $(p=0.052)$ with a moderate ES (Cohen's $d=0.66$ ). 
By contrast, the other four RCTs $[23,65,67,69]$ revealed no significant group differences in the respective effects of $\mathrm{MBCT}$ on salivary cortisol with one-year follow-up in remitted patients with recurrent depression compared to treatment as usual (TAU) [65]; of MAPs on plasma NF-kB in patients with sleep disturbance compared to an education intervention [67]; of mindfulness-based group therapy on plasma IL-8, EGF, and hsCRP in patients with depression or anxiety compared to cognitive behavioural therapy (CBT) [23]; or of mindfulness-based group therapy on leukocyte telomere length in patients with depression or anxiety compared to CBT [69].

With regard to the individual biomarkers, IL- 6 and cortisol were the most frequently reported, each in three articles ([26,65,68,70], respectively). With regard to IL-6, two studies [26,70] measured serum or plasma IL-6 levels, and the other used salivary samples [68]. One study observed that the levels of serum IL-6 in patients with alcohol dependence did not significantly decrease although they showed a trend from baseline to 16-week follow-up $(p=0.052)$ [70]. The other two studies reported that the levels of salivary IL-6 in an MBI group with depressive symptoms significantly decreased within the group between baseline and post-treatment $(p<0.05)$ [68], and the levels of plasma IL-6 AUC concentration in an MBSR group with GAD significantly decreased compared to an education group during the TSST $(p=0.036)$ [26]. For cortisol, two studies used salivary samples $[65,70]$ and the other used plasma samples [26]. There were no significant changes from baseline to the end of intervention or to follow-up in the levels of salivary cortisol in patients with alcohol dependence $(p>0.05)$ [70], or in remitted patients with recurrent depression [65]. In addition, no significant change in plasma cortisol AUC concentrations during the TSST was found between the MBSR group and the education group in patients with GAD $(p=0.38)$ [26].

With regard to CRP, the findings of two studies were consistent: there were no significant changes in the levels of CRP or hsCRP from baseline to post-intervention in patients with MDD or with depression or anxiety $[23,71]$.

\subsection{Low-Grade Inflammation Outcomes Synthesis}

The data synthesis was composed of outcomes from five studies that included comparisons with control groups $[23,26,65,67,68]$, having a total of 405 participants (206 in the MBI groups and 199 in the control groups) and using the following biomarkers: EGF, ACTH, cortisol, IL-6, IL-8, TNF- $\alpha$, NF-kB and hsCRP. Figure 4 shows the Forest Plot for the overall ES found. As can be seen, MBIs showed low but significant effects in improving the state of health related to low-grade inflammation outcomes $(g=-0.21 ; p=0.043 ; \mathrm{NNT}=8.47)$, with no heterogeneity $\left(I^{2}=0 ; 95 \% \mathrm{CI}=0-79 ; p=0.976\right)$. No indication of publication bias was found in the overall estimate (Begg tau $=0.40, p=0.231$; Egger intercept -0.22 , $p=0.389$ ). Duval and Tweedie's trim and fill procedure did not propose the addition of new imputed studies. Because of the limited number of studies, a post-hoc power calculation was conducted to examine whether a sufficient number of studies and sample sizes had been taken into consideration in order to identify relevant effects. These calculations indicated that the inclusion of five studies, with a mean sample size of 41 participants per condition, a low degree of heterogeneity assumed and a significance level of $\alpha=0.05$, resulted in a statistical power of 0.47 , in order to detect an ES of -0.21 . 


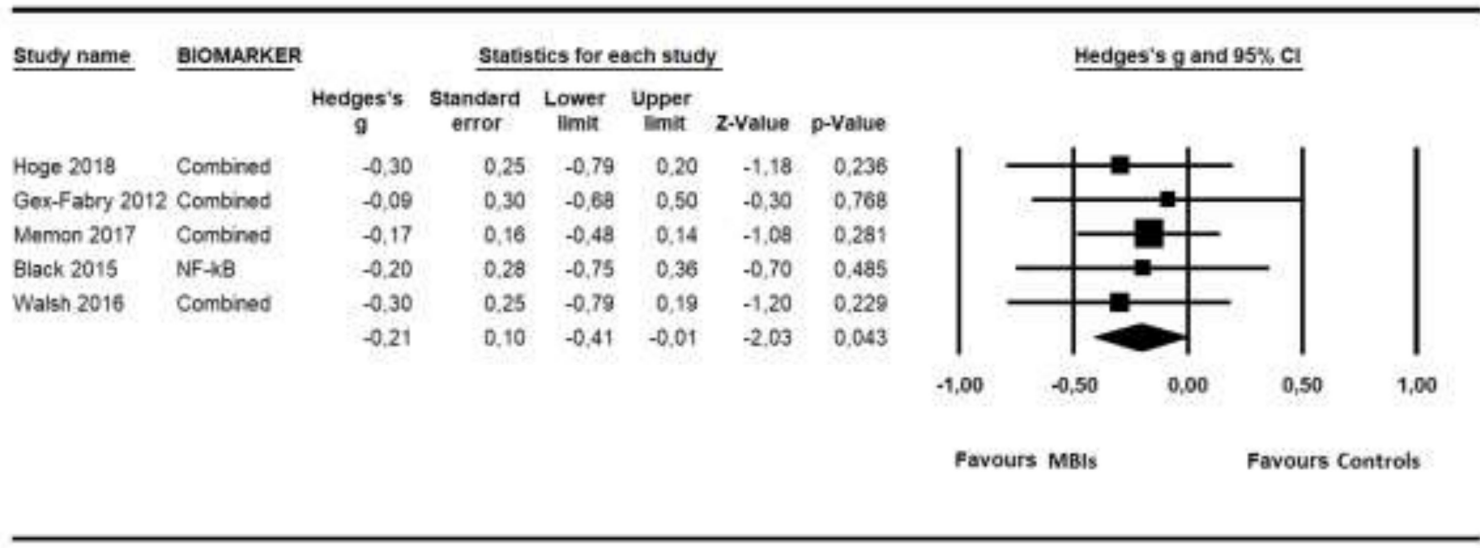

Figure 4. Forest Plot for the overall effect size of low-grade inflammatory biomarkers.

\section{Discussion}

In this first comprehensive meta-analytic review of the effects of MBIs on biomarkers in patients with psychiatric disorders, it was found that while several types of biomarkers and participants were included and the selected articles were of poor quality, significant findings were observed for MBIs in terms of improvements in the ERP amplitudes in patients with ADHD [66], in the methylation of serotonin transporter genes in patients with PTSD [72], in the salivary levels of IL-6 and TNF- $\alpha$ in participants with depressive symptoms [68] and in the blood levels of ACTH, IL-6, and TNF- $\alpha$ in patients with GAD [26].

With regard to ERP amplitudes, previous studies have generally reported a reduction of P3 amplitudes in adolescents with ADHD compared to control children [73-75]. A recent systematic review noted that $\mathrm{MBI}$ could promote a positive relationship between emotional appraisal of errors and Pe in pre-adolescents [76]. Very few studies have been conducted on the effects of MBIs on ERP amplitudes in adult patients with ADHD. Thus, further studies are needed to examine the effects of MBIs on ERP and, specifically, on whether they have effects in adult patients as well as in adolescent or pre-adolescent patients with ADHD.

With regard to DNA methylation biomarkers, FK506 binding protein 5 (FKBP5) regulates glucocorticoid receptor signalling by decreasing ligand binding and restricting its translocation to the nucleus [77,78]; the FKBP5 gene could be associated with an increased number of lifetime depressive episodes [79]. In line with our results and those of Bishop et al. [72], one study demonstrated that the methylation of FKBP5 promoter decreased in veterans with PTSD who responded to exposure psychotherapy [80]. However, there were no other studies that examined the effects of psychotherapy, including MBIs, on the methylation of the FKBP5 gene in patients with PTSD. Thus, a larger number of studies are needed to clarify the association between FKBP5 gene methylation and symptom severity in this population.

With regard to inflammatory cytokines, a recent meta-analysis found no significant effects of MBIs on the blood levels of IL- 6 and TNF- $\alpha$ in participants with ulcerative colitis or obesity, or in dementia caregivers and healthy subjects [16]. Likewise, two previous systematic reviews reported that null findings of replicated effects of MBIs were observed for inflammatory cytokines in blood, including IL-6 and TNF- $\alpha$, in participants with cancer, ulcerative colitis or rheumatoid arthritis, or in dementia caregivers and healthy controls [1,81]. For ACTH, one study performed by Kim et al. [82] found no significant effects from mindfulness-based stretching and deep breathing exercises based on MBSR on the levels of blood ACTH in nurses with subclinical features of PTSD. However, our findings revealed the positive effects of MBSR training on AUC concentrations for blood ACTH, IL- 6 and TNF- $\alpha$ during the TSST in patients with GAD [26], and of a brief MBI on the levels of salivary IL- 6 and TNF- $\alpha$ in participants with depressive symptomatology [68]. This discrepancy may in part be attributable to 
1) the inadequate statistical power in terms of studies and sample sizes found, and 2) the various types of participants without psychiatric diseases.

We also conducted a meta-analysis to examine the specific effects of MBIs on biomarkers related to low-grade inflammation. We observed low but significant effects in improving the state of health in patients with psychiatric disorders, including MDD, sleep disorder and anxiety disorders. Low-grade inflammation is associated with several major psychiatric disorders, such as MDD, anxiety disorders and schizophrenia. In a previous study [35], the prevalence rates for low-grade systematic inflammation, which was defined by serum CRP $>3 \mathrm{mg} / \mathrm{L}$, in unipolar mood disorder and in neurotic disorders, including anxiety disorders, were $16 \%$ and $22 \%$, respectively. As mentioned earlier, in this review, we treated low-grade inflammation as the comprehensive involvement of the hypothalamic-pituitary-adrenal axis and pro-inflammatory cytokines (Figure 5) and included biomarkers related to low-grade inflammation, such as EGF, ACTH, cortisol, pro-inflammatory cytokines (IL-6, IL-8, TNF- $\alpha$ ), NF-kB and hsCRP. In line with our results for CRP and hsCRP, a recent review from two RCTs concluded that MBIs showed no significant reductions in the inflammatory biomarker CRP in stressed community subjects [32] (this population did not meet our inclusion criteria). However, very few studies have explored the associations between MBIs and biomarkers of low-grade inflammation. Thus, further studies are needed to clarify the extent to which MBIs affect low-grade inflammation in patients with psychiatric disorders and in healthy subjects.

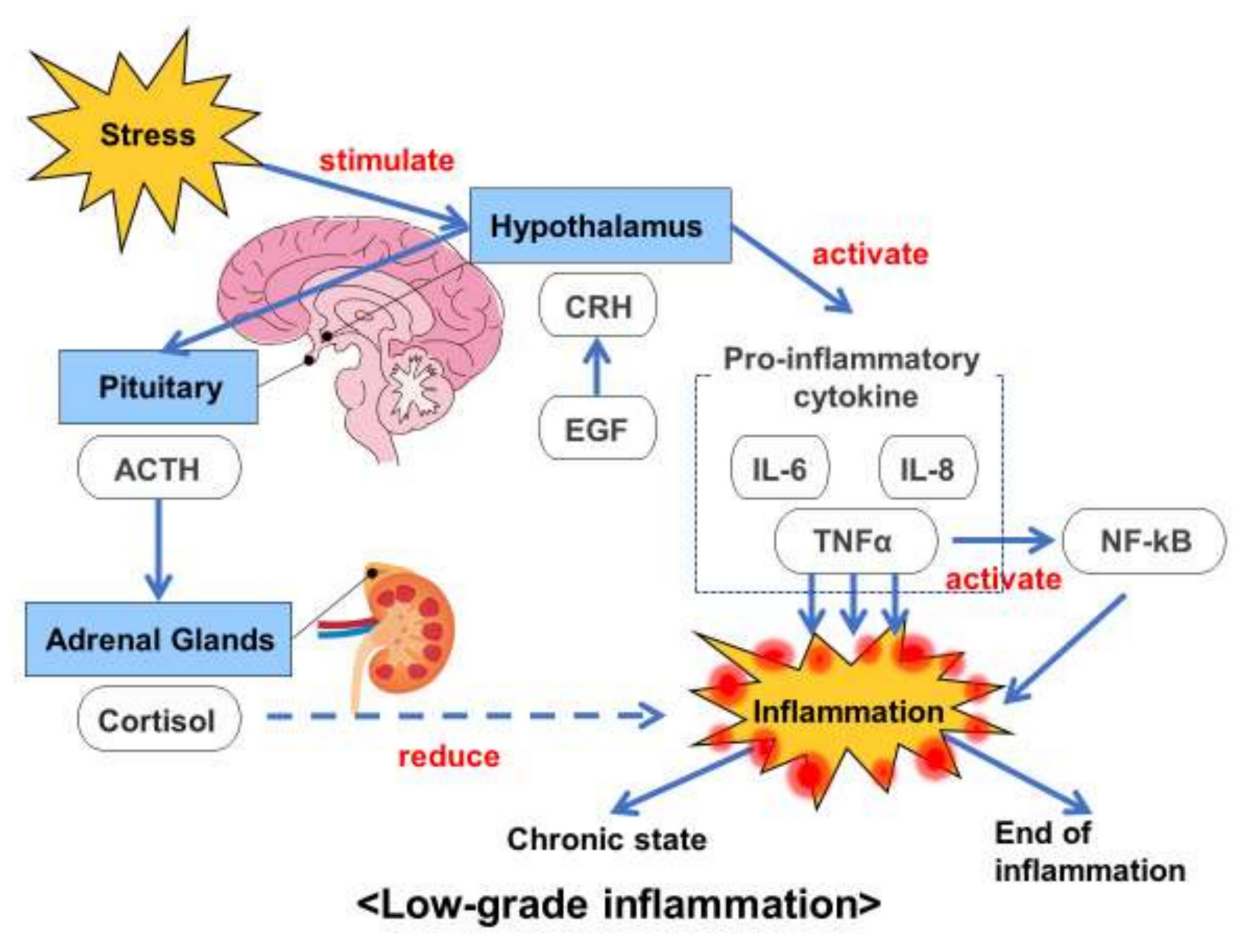

Figure 5. Association between biomarkers of low-grade inflammation and stress.

There are several limitations to the present meta-analytic systematic review. First, our quantitative synthesis has low statistical power due to the scarce number of studies and sample sizes. Therefore, more studies are clearly needed to obtain a powerful analysis. Second, the included studies had various types of biomarkers and patients with psychiatric disorders, and sub-group analyses could not be carried out due to the insufficient number of studies. Third, the included studies had a great diversity of control groups: waiting list, education, TAU and CBT. Fourth, most of the studies showed a high risk of bias; thus, studies of higher quality are needed. Fifth, the quality of interventions in most studies was rather low. Despite the limitations mentioned, this kind of work could help to overcome those shortcomings linked to the only use of self-report measures of trait 
mindfulness when using MBIs to treat psychiatric disorders, proposing possible biomarkers that could function as mechanisms of action in this specific type of interventions and populations.

In conclusion, our findings indicate that MBIs seems to be associated with significant improvements in the ERP amplitudes in patients with ADHD, in the methylation of serotonin transporter genes in patients with PTSD, in the salivary levels of IL- 6 and TNF- $\alpha$ in participants with depressive symptoms and in the blood levels of ACTH, IL- 6 and TNF- $\alpha$ in patients with GAD. In addition, MBIs seems to be related to a low but significant improvement in health status related to biomarkers of low-grade inflammation. In light of the small ES observed; however, further studies are required to improve the understanding of the effects of MBIs on biomarkers in psychiatric disorders.

Author Contributions: K.S., J.M.-M., M.D. and J.G.C. designed the research protocol; D.I., M.O., A.H., A.Y., M.S.V. and K.S. selected studies to be included; A.B.-S., A.H. and K.S. curated the data; J.M.-M. undertook the statistical analysis; K.S., R.H. and A.B.-S. drafted the first manuscript, and J.M.-M., M.D., J.G.C. and A.I. reviewed and made contributions to the text. All authors have read and agreed to the published version of the manuscript.

Funding: This research did not receive any specific grant from funding agencies in the public, commercial, or not-for-profit sectors. Jesus Montero-Marin is supported by the Wellcome Trust Grant (104908/Z/14/Z).

Acknowledgments: We extend our gratitude to all the authors of the included studies, particularly Elizabeth Hoge and Marianne Gex-Fabry for kindly providing unpublished data.

Conflicts of Interest: Within the past three years, Kenji Sanada has received a research grant from Japan Dairy Association (J-milk) and speaker's honoraria from Eli Lilly and Dainippon Sumitomo Pharma.

\section{References}

1. Sanada, K.; Alda, D.M.; Salas, V.M.; Pérez-Yus, M.C.; Demarzo, M.M.; Montero-Marín, J.; García-Toro, M.; García-Campayo, J. Effects of mindfulness-based interventions on biomarkers in healthy and cancer populations: A systematic review. BMC Complement. Altern. Med. 2017, 17, 125. [CrossRef] [PubMed]

2. Kabat-Zinn, J. Full Catastrophe Living: Using the Wisdom of Your Body and Mind to Face Stress, Pain, and Illness; Dell Publishing: New York, NY, USA, 1990.

3. Kabat-Zinn, J. Mindfulness-based interventions in context: Past, present, and future. Clin. Psychol. 2003, 10, $144-156$. [CrossRef]

4. Kabat-Zinn, J. An outpatient program in behavioral medicine for chronic pain patients based on the practice of mindfulness meditation: Theoretical considerations and preliminary results. Gen. Hosp. Psychiatry 1982, 4, $33-47$. [CrossRef]

5. Segal, Z.; Williams, J.; Teasdale, J. Mindfulness-Based Cognitive Therapy for Depression: A New Approach to Preventing Relapse; Guilford Press: New York, NY, USA, 2002.

6. Witkiewitz, K.; Marlatt, G.A.; Walker, D. Mindfulness-Based Relapse Prevention for Alcohol and Substance Use Disorders. J. Cogn. Psychother. 2005, 19, 211-228. [CrossRef]

7. Bowen, S.; Chawla, N.; Marlatt, G. Mindfulness-Based Relapse Prevention for Addictive Behaviors: A Clinician's Guide; Guilford Press: New York, NY, USA, 2010.

8. Sanada, K.; Montero-Marin, J.; Alda, D.M.; Salas-Valero, M.; Pérez-Yus, M.C.; Morillo, H.; Demarzo, M.M.; García-Toro, M.; García-Campayo, J. Effects of Mindfulness-Based Interventions on Salivary Cortisol in Healthy Adults: A Meta-Analytical Review. Front. Physiol. 2016, 7, 471. [CrossRef] [PubMed]

9. Goldberg, S.B.; Tucker, R.P.; Greene, P.A.; Davidson, R.J.; Wampold, B.E.; Kearney, D.J.; Simpson, T.L. Mindfulness-based interventions for psychiatric disorders: A systematic review and meta-analysis. Clin. Psychol. Rev. 2018, 59, 52-60. [CrossRef] [PubMed]

10. Montero-Marin, J.; Garcia-Campayo, J.; Pérez-Yus, M.C.; Zabaleta-Del-Olmo, E.; Cuijpers, P. Meditation techniques $v$. relaxation therapies when treating anxiety: A meta-analytic review. Psychol. Med. 2019, 49, 2118-2133. [CrossRef]

11. Kuyken, W.; Byford, S.; Taylor, R.S.; Watkins, E.; Holden, E.; White, K.; Barrett, B.; Byng, R.; Evans, A.; Mullan, E.; et al. Mindfulness-based cognitive therapy to prevent relapse in recurrent depression. J. Consult. Clin. Psychol. 2008, 76, 966-978. [CrossRef]

12. Kogan, M.; Kligler, B. Mind-Body Medicine Therapies for a Range of Depression Severity: A Systematic Review. Psychosomatics 2012, 53, 407-423. 
13. Strauss, C.; Cavanagh, K.; Oliver, A.; Pettman, D. Mindfulness-based interventions for people diagnosed with a current episode of an anxiety or depressive disorder: A meta-analysis of randomised controlled trials. PLoS ONE 2014, 9, e96110. [CrossRef]

14. Hofmann, S.G.; Sawyer, A.T.; Witt, A.A.; Oh, D. The Effect of Mindfulness-Based Therapy on Anxiety and Depression: A Meta-Analytic Review. J. Consult. Clin. Psychol. 2010, 78, 169-183. [CrossRef] [PubMed]

15. Vøllestad, J.; Nielsen, M.B.; Nielsen, G.H. Mindfulness- and acceptance-based interventions for anxiety disorders: A systematic review and meta-analysis. Br. J. Clin. Psychol. 2012, 51, 239-260. [CrossRef] [PubMed]

16. Pascoe, M.C.; Thompson, D.R.; Jenkins, Z.M.; Ski, C.F. Mindfulness mediates the physiological markers of stress: Systematic review and meta-analysis. J. Psychiatry Res. 2017, 95, 156-178. [CrossRef] [PubMed]

17. Karyadi, K.A.; Vanderveen, J.D.; Cyders, M.A. A Meta-Analysis of the Relationship between Trait Mindfulness and Substance Use Behaviors. Drug Alcohol Depend. 2014, 143, 1-10. [CrossRef]

18. Grant, S.; Colaiaco, B.; Motala, A.; Shanman, R.; Booth, M.; Sorbero, M.; Hempel, S. Mindfulness-based Relapse Prevention for Substance Use Disorders: A Systematic Review and Meta-analysis. J. Addict. Med. 2017, 11, 386-396. [CrossRef]

19. Li, W.; Howard, M.O.; Garland, E.L.; Mcgovern, P.; Lazar, M. Mindfulness treatment for substance misuse: A systematic review and meta-analysis. J. Subst. Abuse Treat. 2017, 75, 62-96. [CrossRef]

20. Winbush, N.Y.; Gross, C.R.; Kreitzer, M.J. The effects of Mindfulness-Based Stress Reduction on sleep disturbance: A systematic review. Explore 2007, 3, 585-591. [CrossRef]

21. Gong, H.; Ni, C.; Liu, Y.; Zhang, Y.; Su, W.; Lian, Y.; Peng, W.; Jiang, C. Mindfulness meditation for insomnia: A meta-analysis of randomized controlled trials. J. Psychosom. Res. 2016, 89, 1-6. [CrossRef]

22. Lakhan, S.E.; Schofield, K.L. Mindfulness-Based Therapies in the Treatment of Somatization Disorders: A Systematic Review and Meta-Analysis. PLoS ONE 2013, 8, e71834. [CrossRef]

23. Memon, A.A.; Sundquist, K.; Ahmad, A.; Wang, X.; Hedelius, A.; Sundquist, J. Role of IL-8, CRP and epidermal growth factor in depression and anxiety patients treated with mindfulness-based therapy or cognitive behavioral therapy in primary health care. Psychiatry Res. 2017, 254, 311-316. [CrossRef]

24. Reich, R.R.; Lengacher, C.A.; Klein, T.W.; Newton, C.; Shivers, S.; Ramesar, S.; Alinat, C.B.; Paterson, C.; Le, A.; Park, J.Y.; et al. A Randomized Controlled Trial of the Effects of Mindfulness-Based Stress Reduction (MBSR[BC]) on Levels of Inflammatory Biomarkers Among Recovering Breast Cancer Survivors. Biol. Res. Nurs. 2017, 19, 456-464. [CrossRef] [PubMed]

25. Dada, T.; Mittal, D.; Mohanty, K.; Faiq, M.A.; Bhat, M.A.; Yadav, R.K.; Sihota, R.; Sidhu, T.; Velpandian, T.; Kalaivani, M.; et al. Mindfulness Meditation Reduces Intraocular Pressure, Lowers Stress Biomarkers and Modulates Gene Expression in Glaucoma: A Randomized Controlled Trial. J. Glaucoma 2018, 27, 1061-1067. [CrossRef] [PubMed]

26. Hoge, E.A.; Bui, E.; Palitz, S.A.; Schwarz, N.R.; Owens, M.E.; Johnston, J.M.; Pollack, M.H.; Simon, N.M. The effect of mindfulness meditation training on biological acute stress responses in generalized anxiety disorder. Psychiatry Res. 2018, 262, 328-332. [CrossRef]

27. Barrett, B.; Hayney, M.S.; Muller, D.; Rakel, D.; Brown, R.; Zgierska, A.E.; Barlow, S.; Hayer, S.; Barnet, J.H.; Torres, E.R.; et al. Meditation or exercise for preventing acute respiratory infection (MEPARI-2): A randomized controlled trial. PLoS ONE 2018, 13, e0197778. [CrossRef] [PubMed]

28. Carlson, L.E.; Speca, M.; Faris, P.; Patel, K.D. One year pre-post intervention follow-up of psychological, immune, endocrine and blood pressure outcomes of mindfulness-based stress reduction (MBSR) in breast and prostate cancer outpatients. Brain Behav. Immun. 2007, 21, 1038-1049. [CrossRef] [PubMed]

29. Witek-Janusek, L.; Albuquerque, K.; Chroniak, K.R.; Chroniak, C.; Durazo-Arvizu, R.; Mathews, H.L. Effect of mindfulness based stress reduction on immune function, quality of life and coping in women newly diagnosed with early stage breast cancer. Brain Behav. Immun. 2008, 22, 969-981. [CrossRef]

30. Lengacher, C.A.; Kip, K.E.; Post-White, J.; Fitzgerald, S.; Newton, C.; Barta, M.; Jacobsen, P.B.; Shelton, M.M.; Moscoso, M.; Johnson-Mallard, V.; et al. Lymphocyte recovery after breast cancer treatment and mindfulness-based stress reduction (MBSR) therapy. Biol. Res. Nurs. 2013, 15, 37-47. [CrossRef]

31. Johnson, D.C.; Thom, N.J.; Stanley, E.A.; Haase, L.; Simmons, A.N.; Shih, P.A.; Thompson, W.K.; Potterat, E.G.; Minor, T.R.; Paulus, M.P. Modifying resilience mechanisms in at-risk individuals: A controlled study of mindfulness training in Marines preparing for deployment. Am. J. Psychiatry 2014, 171, 844-853. [CrossRef] 
32. Villalba, D.K.; Lindsay, E.K.; Marsland, A.L.; Greco, C.M.; Young, S.; Brown, K.W.; Smyth, J.M.; Walsh, C.P.; Gray, K.; Chin, B.; et al. Mindfulness training and systemic low-grade inflammation in stressed community adults: Evidence from two randomized controlled trials. PLoS ONE 2019, 14, e0219120. [CrossRef]

33. Lopresti, A.L.; Maker, G.L.; Hood, S.D.; Drummond, P.D. A review of peripheral biomarkers in major depression: The potential of inflammatory and oxidative stress biomarkers. Prog. Neuropsychopharmacol. Biol. Psychiatry 2014, 48, 102-111. [CrossRef]

34. Yao, H.; Mizoguchi, Y.; Monji, A.; Yakushiji, Y.; Takashima, Y.; Uchino, A.; Yuzuriha, T.; Hashimoto, M. Low-Grade Inflammation Is Associated with Apathy Indirectly via Deep White Matter Lesions in Community-Dwelling Older Adults: The Sefuri Study. Int. J. Mol. Sci. 2019, 20, 1905. [CrossRef] [PubMed]

35. Osimo, E.F.; Cardinal, R.N.; Jones, P.B.; Khandaker, G.M. Prevalence and correlates of low-grade systemic inflammation in adult psychiatric inpatients: An electronic health record-based study. Psychoneuroendocrinology 2018, 91, 226-234. [CrossRef] [PubMed]

36. Moher, D.; Liberati, A.; Tetzlaff, J.; Altman, D.G.; PRISMA Group. Preferred reporting items for systematic reviews and meta-analyses: The PRISMA statement. Int. J. Surg. 2010, 8, 336-341. [CrossRef] [PubMed]

37. Higgins, J.P.T.; Green, S. Cochrane Handbook for Systematic Reviews of Interventions; Version 5.1.0. (Updated March 2011); The Cochrane Collaboration: Oxford, UK, 2011.

38. Lahera, G.; Bayón, C.; Bravo-Ortiz, M.F.; Rodríguez-Vega, B.; Barbeito, S.; Sáenz, M.; Avedillo, C.; Villanueva, R.; Ugarte, A.; González-Pinto, A.; et al. Mindfulness-based cognitive therapy versus psychoeducational intervention in bipolar outpatients with sub-threshold depressive symptoms: A randomized controlled trial. BMC Psychiatry 2014, 14, 215. [CrossRef]

39. Ruffault, A.; Carette, C.; Lurbe, I.; Puerto, K.; Juge, N.; Beauchet, A.; Benoliel, J.J.; Lacorte, J.M.; Fournier, J.F.; Czernichow, S.; et al. Randomized controlled trial of a 12-month computerized mindfulness-based intervention for obese patients with binge eating disorder: The MindOb study protocol. Contemp. Clin. Trials. 2016, 49, 126-133. [CrossRef]

40. Ashton, N.J.; Hye, A.; Leckey, C.A.; Jones, A.R.; Gardner, A.; Elliott, C.; Wetherell, J.L.; Lenze, E.J.; Killick, R.; Marchant, N.L. Plasma REST: A novel candidate biomarker of Alzheimer's disease is modified by psychological intervention in an at-risk population. Transl. Psychiatry 2017, 7, e1148. [CrossRef]

41. Higgins, J.P.T.; Altman, D.G.; Gøtzsche, P.C.; Jüni, P.; Moher, D.; Oxman, A.D.; Savovic, J.; Schulz, K.F.; Weeks, L.; Sterne, J.A.; et al. The Cochrane Collaboration's tool for assessing risk of bias in randomised trials. BMJ 2011, 343, d5928. [CrossRef]

42. Chambless, D.L.; Hollon, S.D. Defining empirically supported therapies. J. Consult. Clin. Psychol. 1998, 66, 7-18. [CrossRef]

43. Evans, J.F.; Ragolia, L. Systemic and local ACTH produced during inflammatory states promotes osteochondrogenic mesenchymal cell differentiation contributing to the pathologic progression of calcified atherosclerosis. Med. Hypotheses 2012, 79, 823-826. [CrossRef]

44. Brown, E.S.; Varghese, F.P.; McEwen, B.S. Association of depression with medical illness: Does cortisol play a role? Biol. Psychiatry 2004, 55, 1-9. [CrossRef]

45. Lovell, B.; Moss, M.; Wetherell, M.A. Perceived stress, on health complaints and diurnal patterns of cortisol secretion in young, otherwise healthy individuals. Horm. Behav. 2011, 60, 301-305. [CrossRef] [PubMed]

46. Clow, A.; Thorn, L.; Evans, P.; Hucklebridge, F. The awakening cortisol response: Methodological issues and significance. Stress 2004, 7, 29-37. [CrossRef] [PubMed]

47. Chida, Y.; Steptoe, A. Cortisol awakening response and psychosocial factors: A systematic review and meta-analysis. Biol. Psychol. 2009, 80, 265-278. [CrossRef] [PubMed]

48. Hsiao, F.H.; Yang, T.T.; Ho, R.T.; Jow, G.M.; Ng, S.M.; Chan, C.L.; Lai, Y.M.; Chen, Y.T.; Wang, K.C. The self-perceived symptom distress and health-related conditions associated with morning to evening diurnal cortisol patterns in outpatients with major depressive disorder. Psychoneuroendocrinology 2010, 35, 503-515. [CrossRef] [PubMed]

49. Stawski, R.S.; Almeida, D.M.; Lachman, M.E.; Tun, P.A.; Rosnick, C.B.; Seeman, T. Associations between cognitive function and naturally occurring daily cortisol during middle adulthood: Timing is everything. J. Gerontol. B. Psychol. Sci. Soc. Sci. 2011, 66, i71-i81. [CrossRef] [PubMed]

50. Malcangio, M.; Bowery, N.G.; Flower, R.J.; Perretti, M. Effect of interleukin-1 beta on the release of substance P from rat isolated spinal cord. Eur. J. Pharmacol. 1996, 299, 113-118. [CrossRef] 
51. Wallace, D.J.; Linker-Israeli, M.; Hallegua, D.; Silverman, S.; Silver, D.; Weisman, M.H. Cytokines play an aetiopathogenetic role in fibromyalgia: A hypothesis and pilot study. Rheumatology 2001, 40, 743-749. [CrossRef] [PubMed]

52. Wang, H.; Moser, M.; Schiltenwolf, M.; Buchner, M. Circulating cytokine levels compared to pain in patients with fibromyalgia-A prospective longitudinal study over 6 months. J. Rheumatol. 2008, 35, 1366-1370. [PubMed]

53. Sethi, G.G.; Sung, B.; Aggarwal, B.B. Nuclear factor-kappaB activation: From bench to bedside. Exp. Biol. Med. 2008, 233, 21-31. [CrossRef] [PubMed]

54. Yousuf, O.; Mohanty, B.D.; Martin, S.S.; Joshi, P.H.; Blaha, M.J.; Nasir, K.; Blumenthal, R.S.; Budoff, M.J. High-sensitivity C-reactive protein and cardiovascular disease: A resolute belief or an elusive link? J. Am. Coll. Cardiol. 2013, 62, 397-408. [CrossRef]

55. Wallensten, J.; Åsberg, M.; Nygren, Å.; Szulkin, R.; Wallén, H.; Mobarrez, F.; Nager, A. Possible biomarkers of chronic stress induced exhaustion-A longitudinal study. PLoS ONE 2016, 11, e0153924. [CrossRef] [PubMed]

56. Yamamori, H.; Ishima, T.; Yasuda, Y.; Fujimoto, M.; Kudo, N.; Ohi, K.; Hashimoto, K.; Takeda, M.; Hashimoto, R. Assessment of multi-assay biological diagnostic test for mood disorders in a Japanese population. Neurosci. Lett. 2016, 612, 167-171. [CrossRef]

57. Hedges, L.V. Distribution theory for Glass's estimator of effect size and related estimators. J. Educ. Behav. Stat. 1981, 6, 107-128. [CrossRef]

58. Furukawa, T.A.; Leucht, S. How to obtain NNT from Cohen's d: Comparison of two methods. PLoS ONE 2011, 6, e19070. [CrossRef]

59. Laupacis, A.; Sackett, D.L.; Roberts, R.S. An assessment of clinically useful measures of the consequences of treatment. N. Engl. J. Med. 1988, 318, 1728-1733. [CrossRef] [PubMed]

60. Borenstein, M.; Hedges, L.V.; Higgins, J.P.T.; Rothstein, H.R. Introduction to Meta-Analysis; John Wiley \& Sons, Ltd: Chichester, UK, 2009.

61. Vevea, J.L.; Woods, C.M. Publication bias in research synthesis: Sensitivity analysis using a priori weight functions. Psychol. Methods. 2005, 10, 428-443. [CrossRef]

62. Egger, M.; Smith, G.D.; Schneider, M.; Minder, C. Bias in meta-analysis detect by a simple, graphical test. BMJ 1997, 315, 629-634. [CrossRef]

63. Duval, S.; Tweedie, R. Trim and fill: A simple funnel-plot-based method. Biometrics 2000, 56, 455-463. [CrossRef]

64. Begg, C.B.; Mazumbar, M. Operating characteristics of a rank correlation test for publication bias. Biometrics 1994, 50, 1088-1101. [CrossRef]

65. Gex-Fabry, M.; Jermann, F.; Kosel, M.; Rossier, M.F.; Van der Linden, M.; Bertschy, G.; Bondolfi, G.; Aubry, J.M. Salivary cortisol profiles in patients remitted from recurrent depression: One-year follow-up of a mindfulness-based cognitive therapy trial. J. Psychiatr. Res. 2012, 46, 80-86. [CrossRef]

66. Schoenberg, P.L.; Hepark, S.; Kan, C.C.; Barendregt, H.P.; Buitelaar, J.K.; Speckens, A.E. Effects of mindfulness-based cognitive therapy on neurophysiological correlates of performance monitoring in adult attention-deficit/hyperactivity disorder. Clin. Neurophysiol. 2014, 125, 1407-1416. [CrossRef] [PubMed]

67. Black, D.S.; O’Reilly, G.A.; Olmstead, R.; Breen, E.C.; Irwin, M.R. Mindfulness meditation and improvement in sleep quality and daytime impairment among older adults with sleep disturbances: A randomized clinical trial. JAMA Intern. Med. 2015, 175, 494-501. [CrossRef] [PubMed]

68. Walsh, E.; Eisenlohr-Moul, T.; Baer, R. Brief mindfulness training reduces salivary IL- 6 and TNF- $\alpha$ in young women with depressive symptomatology. J. Consult. Clin. Psychol. 2016, 84, 887-897. [CrossRef] [PubMed]

69. Wang, X.; Sundquist, K.; Hedelius, A.; Palmér, K.; Memon, A.A.; Sundquist, J. Leukocyte telomere length and depression, anxiety and stress and adjustment disorders in primary health care patients. BMC Psychiatry 2017, 17, 148. [CrossRef] [PubMed]

70. Zgierska, A.; Rabago, D.; Zuelsdorff, M.; Coe, C.; Miller, M.; Fleming, M. Mindfulness meditation for alcohol relapse prevention: A feasibility pilot study. J. Addict. Med. 2008, 2, 165-173. [CrossRef] [PubMed]

71. Eisendrath, S.J.; Gillung, E.; Hartzler, A.; James-Myers, M.; Wolkowitz, O.; Sipe, W.; Ramanatham, D.; Delucchi, K. Mindfulness-based cognitive therapy associated with decreases in C-reactive protein in major depressive disorder: A pilot study. J. Altern. Complement. Integr. Med. 2016, 2, 010. [CrossRef] 
72. Bishop, J.R.; Lee, A.M.; Mills, L.J.; Thuras, P.D.; Eum, S.; Clancy, D.; Erbes, C.R.; Polusny, M.A.; Lamberty, G.J.; Lim, K.O. Methylation of FKBP5 and SLC6A4 in relation to treatment response to mindfulness based stress reduction for posttraumatic stress disorder. Front. Psychiatry 2018, 9, 418. [CrossRef]

73. Johnstone, S.J.; Barry, R.J. Auditory event-related potentials in a two-tone discrimination paradigm in attention deficit hyperactivity disorder. Psychiatry Res. 1996, 64, 179-192. [CrossRef]

74. Karayanidis, F.; Robaey, P.; Bourassa, M.; de Koning, D.; Geoffroy, G.; Pelletier, G. ERP differences in visual attention processing between attention-deficit hyperactivity disorder and control boys in the absence of performance differences. Psychophysiology 2000, 37, 319-333. [CrossRef]

75. Benikos, N.; Johnstone, S.J. Arousal-state modulation in children with AD/HD. Clin. Neurophysiol. 2009, 120, 30-40. [CrossRef]

76. Kaunhoven, R.J.; Dorjee, D. How does mindfulness modulate self-regulation in pre-adolescent children? An integrative neurocognitive review. Neurosci. Biobehav. Rev. 2017, 74, 163-184. [CrossRef] [PubMed]

77. Stechschulte, L.A.; Sanchez, E.R. FKBP51-A selective modulator of glucocorticoid and androgen sensitivity. Curr. Opin. Pharmacol. 2011, 11, 332-337. [CrossRef] [PubMed]

78. Zannas, A.S.; Binder, E.B. Gene-environment interactions at the FKBP5 locus: Sensitive periods, mechanisms and pleiotropism. Genes Brain Behav. 2014, 13, 25-37. [CrossRef]

79. Binder, E.B.; Salyakina, D.; Lichtner, P.; Wochnik, G.M.; Ising, M.; Pütz, B.; Papiol, S.; Seaman, S.; Lucae, S.; Kohli, M.A.; et al. Polymorphisms in FKBP5 are associated with increased recurrence of depressive episodes and rapid response to antidepressant treatment. Nat. Genet. 2004, 36, 1319-1325. [CrossRef]

80. Yehuda, R.; Daskalakis, N.P.; Desarnaud, F.; Makotkine, I.; Lehrner, A.L.; Koch, E.; Flory, J.D.; Buxbaum, J.D.; Meaney, M.J.; Bierer, L.M. Epigenetic biomarkers as predictors and correlates of symptom improvement following psychotherapy in combat veterans with PTSD. Front. Psychiatry 2013, 4, 118. [CrossRef]

81. Black, D.S.; Slavich, G.M. Mindfulness meditation and the immune system: A systematic review of randomized controlled trials. Ann. N. Y. Acad. Sci. 2016, 1373, 13-24. [CrossRef]

82. Kim, S.H.; Schneider, S.M.; Bevans, M.; Kravitz, L.; Mermier, C.; Qualls, C.; Burge, M.R. PTSD symptom reduction with mindfulness-based stretching and deep breathing exercise: Randomized controlled clinical trial of efficacy. J. Clin. Endocrinol. Metab. 2013, 98, 2984-2992. [CrossRef] [PubMed]

(C) 2020 by the authors. Licensee MDPI, Basel, Switzerland. This article is an open access article distributed under the terms and conditions of the Creative Commons Attribution (CC BY) license (http://creativecommons.org/licenses/by/4.0/). 